\title{
Significant $\mathrm{CO}_{2}$ fixation by small prymnesiophytes in the subtropical and tropical northeast Atlantic Ocean
}

\author{
Ludwig Jardillier ${ }^{1,3}$, Mikhail V Zubkov², John Pearman ${ }^{1}$ and David J Scanlan ${ }^{1}$ \\ ${ }^{1}$ Department of Biological Sciences, University of Warwick, Coventry, UK and ${ }^{2}$ National Oceanography \\ Centre, Southampton, Hampshire, UK
}

\begin{abstract}
Global estimates indicate the oceans are responsible for approximately half of the carbon dioxide fixed on Earth. Organisms $\leqslant 5 \mu \mathrm{m}$ in size dominate open ocean phytoplankton communities in terms of abundance and $\mathrm{CO}_{2}$ fixation, with the cyanobacterial genera Prochlorococcus and Synechococcus numerically the most abundant and more extensively studied compared with small eukaryotes. However, the contribution of specific taxonomic groups to marine $\mathrm{CO}_{2}$ fixation is still poorly known. In this study, we show that among the phytoplankton, small eukaryotes contribute significantly to $\mathrm{CO}_{2}$ fixation (44\%) because of their larger cell volume and thereby higher cell-specific $\mathrm{CO}_{2}$ fixation rates. Within the eukaryotes, two groups, herein called Euk-A and Euk-B, were distinguished based on their flow cytometric signature. Euk-A, the most abundant group, contained cells $1.8 \pm 0.1 \mu \mathrm{m}$ in size while Euk-B was the least abundant but cells were larger $(2.8 \pm 0.2 \mu \mathrm{m})$. The Euk-B group comprising prymnesiophytes $(73 \pm 13 \%)$ belonging largely to lineages with no close cultured counterparts accounted for up to $38 \%$ of the total primary production in the subtropical and tropical northeast Atlantic Ocean, suggesting a key role of this group in oceanic $\mathrm{CO}_{2}$ fixation.

The ISME Journal (2010) 4, 1180-1192; doi:10.1038/ismej.2010.36; published online 15 April 2010

Subject Category: geomicrobiology and microbial contributions to geochemical cycles

Keywords: $\mathrm{CO}_{2}$ fixation; primary production; prymnesiophytes; chrysophytes
\end{abstract}

\section{Introduction}

Looking inside the phytoplankton 'black box' to determine the distribution of carbon biomass and group-specific primary production is fundamental to understanding the roles of these groups in the global carbon cycle. The contribution of different phytoplankton communities to primary production has been extensively studied using size fractionation approaches (Teira et al., 2005; Pérez et al., 2006), and revealed a major role of the smallest phytoplankton $(<2-5 \mu \mathrm{m})$ in the open ocean. Direct flow cytometric sorting of these smallest picoplankton cells coupled with radioactive tracer experiments have shown that although cyanobacteria dominated carbon fixation into biomass in the open ocean, nevertheless eukaryotic cells contributed significantly in spite of their lower abundance (Li, 1994). Subsequent studies conducted in both coastal (Worden et al., 2004) and open ocean waters (Goericke, 1998; Grob et al., 2007), which did not

Correspondence: DJ Scanlan, Department of Biological Sciences, University of Warwick, Gibbet Hill Road, Coventry CV4 7AL, UK. E-mail: d.j.scanlan@warwick.ac.uk

${ }^{3}$ Current address: Unité d'Ecologie, Systématique et Evolution, Université Paris-Sud 11, 91405 Orsay cedex, France.

Received 19 October 2009; revised 18 February 2010; accepted 22 February 2010; published online 15 April 2010 involve cell sorting, supported Li's observations. Moreover, studies based on size-fractionated pigment analysis also suggest a wide distribution of these small photosynthetic eukaryotes (Latasa and Bidigare, 1998; Wright et al., 2009). Recent progress using molecular approaches has begun to reveal their diversity (Moon-van der Staay et al., 2000; Díez et al., 2001; Vaulot et al., 2008; Worden and Not, 2008) showing a dominance of prymnesiophytes, pelagophytes and prasinophytes in marine environments (for example, see Moon-van der Staay et al., 2001; Romari and Vaulot, 2004; Not et al., 2004; Fuller et al., 2006a, b; Viprey et al., 2008; Liu et al., 2009) and lately of chrysophytes (Fuller et al., 2006b; McDonald et al., 2007; Lepère et al., 2009). However, we still have a poor understanding of the phylogenetic affiliation of the smallest cells (for example, see Liu et al., 2010), and particularly in directly linking taxonomic identity with ${ }^{14} \mathrm{C}$ primary production measurements. In this study, to determine the precise contributions of different phytoplankton groups to $\mathrm{CO}_{2}$ fixation into biomass in the subtropical and tropical northeast Atlantic Ocean, we used a modified $\mathrm{NaH}^{14} \mathrm{CO}_{3}$ radiotracer incubation flow cytometric sorting approach $(\mathrm{Li}, 1994)$ on board ship with natural communities sampled in surface waters (between 5 and $20 \mathrm{~m}$ ) in which the majority of $\mathrm{CO}_{2}$ fixation is thought to occur 
(Marañón et al., 2000; Poulton et al., 2006; Morán, 2007). In conjunction with these carbon fixation measurements, the differentiated phytoplankton groups were phylogenetically affiliated using molecular techniques, including fluorescence in situ hybridization (FISH). In doing so, we reveal that small prymnesiophytes, mostly of taxonomic lineages lacking close cultured counterparts, can contribute significantly to $\mathrm{CO}_{2}$ fixation in the ocean.

\section{Materials and methods}

Sampling and experimental design

Samples were collected on board the Royal Research Ship Discovery during cruise D326 in the subtropical and tropical northeast Atlantic Ocean between 12 January and 1 February 2008 at 18 stations encompassing an area between $12-26^{\circ} \mathrm{N}$ and $24-36^{\circ} \mathrm{W}$ (Figure 1). Seawater samples were collected at dawn with 10 or $20 \mathrm{l}$ Niskin bottles mounted on a conductivity-temperature-fluorescence-depth profiler, with either trace-iron free titanium frame (10l) or metallic frame (20l). All samples were pre-filtered through $100 \mu \mathrm{m}$ pore-size mesh when being decanted from the Niskin bottles, directly into 201 hydrochloric acid washed polycarbonate carboys. Gas tight high-performance liquid chromatography glass vials $(8 \mathrm{ml})$ were then filled with $7.8 \mathrm{ml}$ of sampled water and inoculated with either $74 \mathrm{kBq} \mathrm{NaH}{ }^{14} \mathrm{CO}_{3}$ for determining $\mathrm{CO}_{2}$ fixation into total phototrophic biomass, or $7.4 \mathrm{MBq}$ $\mathrm{NaH}^{14} \mathrm{CO}_{3}^{-}$for assessing the contribution of the

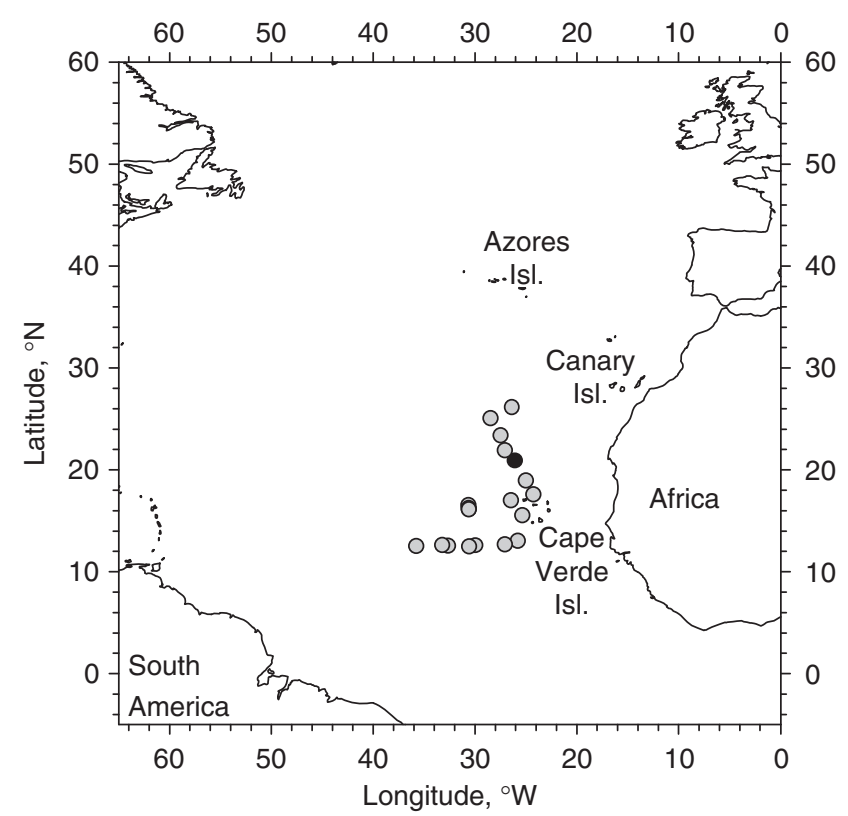

Figure 1 Schematic representation of the D326 cruise track. Circles indicate those stations at which $\mathrm{CO}_{2}$ fixation experiments were performed. The black circle indicates the station (16400A) at which a sample used for clone library construction was collected. different groups of phototrophic microorganisms to $\mathrm{CO}_{2}$ fixation. The vials were then incubated for up to $11 \mathrm{~h}$-an average daylight period at the time of sampling. In situ light conditions on deck were monitored to be approximately $10 \%$ of direct sunlight, while the on deck incubation temperature varied $<8.5 \%$, on average, from in situ conditions. A set of samples was also incubated in the dark to ascertain dark $\mathrm{CO}_{2}$ fixation. Up to 10 vial replicates incubated in the light and 5 vial replicates incubated in the dark were used for each experimental determination of total $\mathrm{CO}_{2}$ fixation by phytoplankton. At each time point $(\sim 3 \mathrm{~h})$, three of the replicate vials were used for $\mathrm{CO}_{2}$ fixation measurement, two as duplicates for light conditions and one for dark conditions. Samples were fixed with $1 \%(\mathrm{w} / \mathrm{v})$ final concentration paraformaldehyde (PFA-SigmaAldrich, Poole, UK) to preserve cell integrity (Zubkov and Leakey, 2009) to enable quantitative comparisons with flow cytometrically sorted cells (see below). Fixed cells were then harvested onto $0.2-\mu \mathrm{m}$ pore-size polycarbonate filters and washed twice with deionized water. A filter was placed in a scintillation vial and $1 \mathrm{ml}$ of $1 \%(\mathrm{v} / \mathrm{v})$ HCl (SigmaAldrich) was added to securely purge the residue of inorganic carbon. Subsequently, $5 \mathrm{ml}$ of scintillation cocktail was added to each vial. The vial content was mixed and left to equilibrate before radioassaying. Radioactivity retained in cells, harvested on filters, was measured using a liquid scintillation counter Tri-Carb 3100 (Perkin Elmer, Cambridge, UK) on board the ship.

\section{Cell enumeration and flow cytometric sorting}

Phytoplankton cells were enumerated by flow cytometry (FACSort-Becton Dickinson, NJ, USA) in seawater samples fixed with 1\% (w/v) PFA final concentration to enable quantitative comparisons with flow cytometrically sorted cells. Previous work has shown no loss of either prokaryotic or eukaryotic cells occurs upon fixation (Zubkov and Burkill, 2006). Synechococcus cells were counted unstained (Zubkov et al., 2000) while eukaryotic phytoplankton and Prochlorococcus were counted after staining with SYBR Green I (Sigma-Aldrich, 1:5000 dilution of the commercial stock; see Zubkov et al., 2000, 2007). Multifluorescence $0.5-\mu \mathrm{m}$ reference beads (fluoresbrite microparticles-Polysciences, Eppelheim, Germany) were used in all analyses as an internal standard for both fluorescence and flow rates. PFA-fixed, ${ }^{14} \mathrm{C}$-labelled Synechococcus and Prochlorococcus cells were flowsorted from unstained samples. PFA-fixed, ${ }^{14} \mathrm{C}-$ labelled eukaryotic cells were flow-sorted from SYBR Green I DNA-stained, unconcentrated samples. Flow sorting of both types of samples was completed within $10 \mathrm{~h}$ of fixation. The FACSort instrument was set at single-cell sort mode (the highest sorting purity of the instrument). Three to five proportional numbers (for example, 200, 400, 
600, 800 and 1000 eukaryotes; 1000, 2000, 3000, 4000, 5000 and 6000 Synechococcus; 3000, 6000, 9000, 12 000, 15000 and 18000 Prochlorococcus) of cells for each target population were sorted. Sorted cells were collected onto $0.2-\mu \mathrm{m}$ pore-size polycarbonate filters (Whatman, UK) and then processed as described above for the total samples. Mean cellular tracer incorporation by phytoplankton cells was determined by regression analysis $\left(r^{2}>0.97\right.$, $P<0.05)$. To evaluate differences in $\mathrm{CO}_{2}$ fixation rates among the different phytoplankton groups a two-tailed $t$-test was used $(P<0.05)$. To assess sorting recovery (Zubkov and Tarran, 2008) total ${ }^{14} \mathrm{C}$ fixation was determined in samples used for flow sorting by filtering six sub-samples (for example, 100, 150, 200, 300, 300 and $450 \mu \mathrm{l}$ ) onto $0.2-\mu \mathrm{m}$ pore-size polycarbonate filters, washed twice with deionized water and radio-assayed as described above.

\section{Fluorescent in situ hybridization}

Seawater samples were amended with $0.05 \%$. (v/v) pluronic solution (Sigma-Aldrich) final concentration to minimize clumping of concentrated cells. Samples (5 l) were then gently filtered through 0.2 $\mu \mathrm{m}$ pore-size CellTrap units (MEM-TEQ Ventures Ltd, Wigan, UK). Concentrated cells were washed off following the manufacturer's recommendations, fixed for $1 \mathrm{~h}$ at $4{ }^{\circ} \mathrm{C}$ with $1 \%(\mathrm{w} / \mathrm{v}) \mathrm{PFA}$, flash frozen in liquid nitrogen and then stored at $-80^{\circ} \mathrm{C}$. Before sorting, samples were slowly defrosted on ice for $1 \mathrm{~h}$ and then stained with SYBR Green I (see above) for sorting eukaryotes or left unstained for sorting cyanobacteria. Samples were diluted with sterile seawater to obtain a flow cytometric counting rate of total particles <1000 particles per second. For each target group, 10000-30000-pigmented cells were sorted by flow cytometry based on endogenous phycoerythrin, chlorophyll $a$ and stained DNA fluorescence signals (see above). Cells were then harvested onto $0.2-\mu \mathrm{m}$ pore-size polycarbonate filters (Whatman), dehydrated in an ethanol series (50\% (v/v), 80\% (v/v) and 100\% (v/v), 3 min each), dried at room temperature and stored at $-80^{\circ} \mathrm{C}$ until analysis. The $16 \mathrm{~S}$ ribosomal RNA (rRNA) oligonucleotide probes used were PRO405 to target all known Prochlorococcus clades as well as the clade-specific probes 645LL, 645HLI and 645HLII (see West et al., 2001). For Synechococcus, the probes used targeted the following specific lineages: clade I (SYN1006), clade II (SYN1006RS), clade III (SYN262), clade IV (SYN635) or more generally clades I-VII and X (SYN1258). The nuclear 18S rRNA oligonucleotide probes used were EUK1209r, NCHLO01 and CHLO02 to target all eukaryotes and the class-specific probes PRAS01, PRAS02, PRAS05 (targeting prasinophytes), and CRYPTO13, PRYM02 and PELA01 targeting cryptophytes, prymnesiophytes and pelagophytes, respectively (Giovannoni et al., 1988; Simon et al., 1995, 2000; Biegala et al.,
2003; Not et al., 2002, 2004). The chrysophytespecific probe (CHRYSO1037) targeted the chloroplast 16S rRNA gene, as used previously for dot blot hybridization analysis (Fuller et al., 2006b) and validated here for tyramide signal amplification (TSA)-FISH analysis (see below). The protocol used for in situ hybridization with horseradish peroxidase-labelled probes has been previously described in Not et al. (2002) for the eukaryote-specific probes and in West et al. (2001) for the cyanobacterial-specific probes. In brief, before hybridization, cyanobacterial cells only were permeabilized by adding $30 \mu \mathrm{l}$ lysozyme solution $\left(5 \mathrm{mg} \mathrm{ml}^{-1}\right.$ dissolved in $100 \mathrm{~mm}$ Tris-HCl, pH 8, $50 \mathrm{mM}$ EDTA-SigmaAldrich) and incubated at $37^{\circ} \mathrm{C}$ for $30 \mathrm{~min}$. Filters were then rinsed with MilliQ water, dehydrated in an ethanol series $(50 \%(\mathrm{v} / \mathrm{v}), 80 \%(\mathrm{v} / \mathrm{v})$ and $100 \%(\mathrm{v} / \mathrm{v}), 3 \mathrm{~min}$ each) and then dried at room temperature. The formamide (Sigma-Aldrich) concentrations used in hybridization buffers containing horseradish peroxidase-labelled probes were as follows: CHRYSO1037, 20\%; EUK1209r, NCHLO01, CHLO02, PRAS01, PRAS02, PRAS05, CRYPTO13, PRYM02, PELA01, 40\% ; 645LL, 645HLII, 50\%; 645HLI, SYN1006, SYN1006RS, SYN262, SYN635, SYN1258, 55\%. Oligonucleotide probes $(2 \mu \mathrm{l}$ of $50 \mathrm{ng} \mu \mathrm{l}^{-1}$ stock) were added to the hybridization buffer (variable \% formamide, $0.9 \mathrm{M} \mathrm{NaCl}, 20 \mathrm{mM}$ Tris-HCl, pH 7.5, 0.01\% (w/v) sodium dodecyl sulphate [SDS]-Sigma-Aldrich) and incubated at $35^{\circ} \mathrm{C}$ for $3-4 \mathrm{~h}$. Filters were then washed twice for $20 \mathrm{~min}$ at $37^{\circ} \mathrm{C}$ in washing buffer (56 mM NaCl, $5 \mathrm{mM}$ EDTA, $0.01 \%$ (w/v) sodium dodecyl sulphate, 20 mM Tris-HCl, pH 7.5). Samples were equilibrated in TNT buffer (100 mM Tris-HCl, pH 7.5, $150 \mathrm{mM}$ NaCl, $0.05 \%$ (v/v) Tween 20-Sigma-Aldrich) for $15 \mathrm{~min}$ at room temperature. TSA (individual fluorescein Tyramide reagent pack-Perkin Elmer) was performed for $30-40 \mathrm{~min}$ at room temperature in the dark in $10 \mu \mathrm{l}$ of TSA mix following the manufacturer's recommendations. Filters were incubated twice at $55{ }^{\circ} \mathrm{C}$ for $20 \mathrm{~min}$ in TNT buffer and then dried at room temperature. Cells were counterstained with propidium iodide (final concentration $10 \mu \mathrm{g} \mathrm{ml} \mathrm{ml}^{-1}$ ) (Foulon et al., 2008) to visualize the nuclei. This allowed verification of labelling eukaryotic cells. Filters were then mounted in anti-fading reagent AF1 (Citifluor, London, UK). Cells were counted within 1 week (Not et al., 2002). The hybridized cells were counted under an Axioskop 40 (Zeiss, Jena, Germany) epifluorescence microscope equipped with a mercury light source and a Plan-Apochromat $\times 100$ (Zeiss) objective. The green (fluorescein isothiocyanate) and red emission (propidium iodide) fluorescence produced by the different fluorochromes was collected between 510 and $550 \mathrm{~nm}$ and above $585 \mathrm{~nm}$. Up to 350 positive cells were counted for the same sample and specific probe (data not shown). The average cell size of flow-sorted Euk-A and Euk-B cells was estimated using the fluorescein 
isothiocyanate signal by measuring at least 500 cells from each group in different samples.

Chrysophyte probe validation and optimization for whole-cell hybridization

The chrysophyte probe used in this study was originally designed by Fuller et al. (2006b) for use in dot blot hybridization analysis and its specificity to chrysophytes has therefore been validated. However, probe specificity was re-checked using our inhouse ARB database containing recently published and unpublished plastid 16S rRNA gene sequences as well as by BLASTn analysis. In silico testing without mismatches revealed that $94.1 \%$ of the eukaryotic sequences (64 of 68 retrieved) were affiliated with chrysophytes. When the four 'other' sequences were inserted into our ARB database, it became apparent that these environmental sequences also grouped with chrysophytes. This analysis also showed that the CHRYSO1037 probe encompassed both marine and freshwater Chrysophyceae, including groups without a cultured representative.

Conditions for in situ hybridization were optimized using different formamide concentrations in the hybridization buffer together with varying the $\mathrm{NaCl}$ concentration in the washing buffer. A marine chrysophyte enrichment culture obtained from the Porcupine Abyssal Plain Observatory in the North Atlantic (L Jardillier and DJ Scanlan, unpublished data) was used as a 'positive' control. Marine representatives of various other photosynthetic eukaryote classes were used as negative controls (Prasinophyceae: RCC827, RCC1124, RCC745; Trebouxiophyceae: RCC289; Chlorophyceae: RCC6; Cryptophyceae: RCC20; Bacillariophyceae: RCC70; Dinophyceae: RCC88; Pelagophyceae: RCC100; Bolidophyceae: RCC205; Prymnesiophyceae: RCC192). Bright and clear FISH signals were obtained with the 'positive' enrichment control while no hybridization was obtained in any of the negative control cultures using the optimized probe conditions. Moreover, a no-probe control showed there was no signal coming from potential endogenous horseradish peroxidases (data not shown).

DNA extraction, clone library construction and phylogenetic analysis

DNA was extracted from 30000 flow-sorted Euk-B cells (station 16400A) concentrated on board following the same procedure as for the FISH method and filtered onto $13 \mathrm{~mm}$ diameter $0.2-\mu \mathrm{m}$. pore-size polycarbonate filters (Whatman). DNA was subsequently extracted using a protocol adapted from Fuller et al. (2003) and Neufeld et al. (2007). Briefly, cells were resuspended in $50 \mu \mathrm{l}$ lysis buffer $(0.75 \mathrm{M}$ sucrose, $400 \mathrm{~mm} \mathrm{NaCl}, 20 \mathrm{~mm}$ EDTA, $50 \mathrm{~mm}$ Tris-HCl [pH 9.0]-Sigma-Aldrich), and then $6 \mu \mathrm{l} 10 \%(\mathrm{w} / \mathrm{v})$ sodium dodecyl sulphate, $10 \mu \mathrm{l} 10 \mathrm{mg} \mathrm{ml}^{-1}$ proteinase
K (Roche, Welwyn Garden City, UK) added. The mix was incubated at $37^{\circ} \mathrm{C}$ for $30 \mathrm{~min}, 55^{\circ} \mathrm{C}$ for $10 \mathrm{~min}$ and then $2 \mu \mathrm{l} 20 \mathrm{mg}^{-1} \mathrm{l}^{-1}$ glycogen (Roche) added to aid DNA recovery. After $5 \mathrm{~min}$ at room temperature, $150 \mu \mathrm{l}$ $100 \%(\mathrm{v} / \mathrm{v})$ ethanol was added and the DNA precipitated by centrifugation. The pellet was washed in $80 \%(\mathrm{v} / \mathrm{v})$ ethanol and finally resuspended in $10 \mu \mathrm{l}$ $10 \mathrm{~mm}$ Tris-HCl [pH 8.0], $0.1 \mathrm{~mm}$ EDTA. Plastid 16S rRNA gene sequences were amplified using primers PLA491F (Fuller et al., 2006a) and OXY1313R (West et al., 2001). PCR amplification was performed in a total reaction volume of $50 \mu \mathrm{l}$ using $200 \mu \mathrm{M}$ deoxynucleotide triphosphates, $1.2 \mathrm{mM} \mathrm{MgCl}_{2}, 0.4 \mu \mathrm{M}$ of primers and $2.4 \mathrm{U}$ Taq polymerase in $1 \times$ enzyme buffer (Qiagen, Crawley, UK) with $1 \mathrm{mg} \mathrm{ml}^{-1}$ bovine serum albumin (Roche). Amplification conditions comprised $95{ }^{\circ} \mathrm{C}$ for $5 \mathrm{~min}$ followed by a step at $80^{\circ} \mathrm{C}$ for $1 \mathrm{~min}$ when Taq polymerase was added. Then, 30 cycles were performed, of $95{ }^{\circ} \mathrm{C}$ for $30 \mathrm{~s}, 60^{\circ} \mathrm{C}$ for $30 \mathrm{~s}$ and $72{ }^{\circ} \mathrm{C}$ for $40 \mathrm{~s}$ ended by a final extension at $72{ }^{\circ} \mathrm{C}$ for $6 \mathrm{~min}$. PCR gene amplicons were cloned into pCR2.1-TOPO (Invitrogen, Paisley, UK). In all, 96 clones were chosen randomly and sequenced at the NERC Molecular Genetics Facility (Edinburgh, UK). Sequences were screened for the presence of chimeric artefacts using Chimera check from the Ribosomal Database Project II and Pintail software (http:// www.bioinformatics-toolkit.org). Sequence alignment was performed using the ARB programme (Ludwig et al., 2004). The phylogenetic tree was constructed from sequences $>1200$ nucleotides in length using Jukes-Cantor correction and a maximum frequency filter for plastids that excluded alignment positions with sequence ambiguity or missing data. Shorter sequences were added by parsimony using the same filter. Bootstrap analysis was performed using the ARB parsimony bootstrap algorithm (Ludwig et al., 2004). The sequences reported in this paper have been deposited in Genbank under the following accession numbers: FJ797579-FJ797591 (see also Supplementary Table 1).

\section{Results}

Phytoplankton community composition

Photosynthetic eukaryotes $\left(2.2 \pm 1.2 \times 10^{3}\right.$ cells ml $\left.^{-1}\right)$ were numerically the least abundant component of the phytoplankton, followed by Synechococcus $\left(1.5 \pm 1.6 \times 10^{4} \mathrm{cells} \mathrm{ml}^{-1}\right)$ and then Prochlorococcus (average cell number $2.1 \pm 0.8 \times 10^{5} \mathrm{cells} \mathrm{ml}^{-1}$ ), (Figure 2a, Table 1). Within the eukaryotes, Euk-A were approximately twice as abundant $\left(1.4 \pm 1.1 \times 10^{3} \mathrm{cells} \mathrm{ml}^{-1}\right)$ as Euk-B $\left(0.6 \pm 0.2 \times 10^{3}\right.$ cells $\mathrm{ml}^{-1}$ ). Euk-B represented $0.18-0.43 \%$ of the total oxygenic phototrophic community and 0.04$0.10 \%$ of the total microbial community (Figure $2 \mathrm{~b}$ ).

On average Euk-A cells were $1.8 \pm 0.1 \mu \mathrm{m}$ in size and Euk-B cells $2.8 \pm 0.2 \mu \mathrm{m}$ (Table 1). The size of cyanobacteria (Prochlorococcus $0.5 \pm 0.2 \mu \mathrm{m}$; Synechococcus $1.0 \pm 0.3 \mu \mathrm{m}$ ) were determined by size 
1184
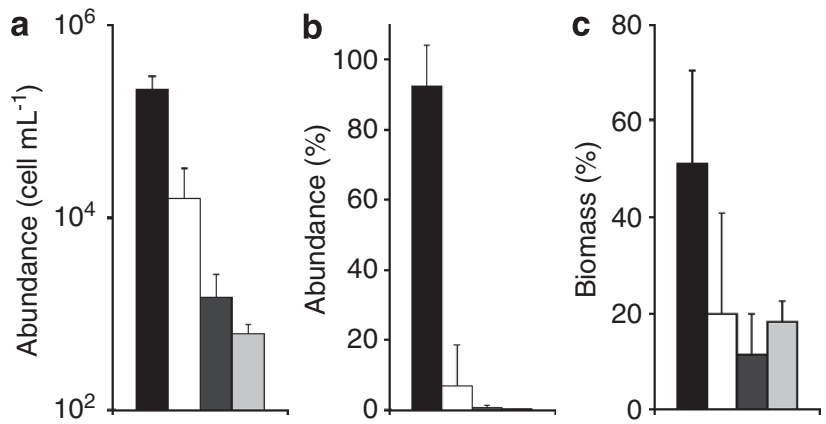

\section{- Prochlorococcus \\ $\square$ Synechococcus \\ - Euk-A \\ $\square$ Euk-B}

Figure 2 Composition of small phytoplankton in the studied area-(a) average cell abundance of the identified phytoplankton groups: Prochlorococcus, Synechococcus, and eukaryotes Euk-A and Euk-B; mean group \% contribution to the total phytoplankton community in terms of (b) cell numbers and (c) biomass.

fractionation on earlier cruises in the same area (Zubkov et al., 2000). A general biomass conversion

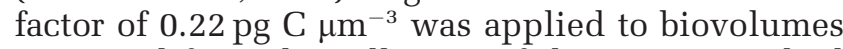
estimated from the cell sizes of the groups studied assuming a spherical shape (Table 1). Proportional to their numerical abundance, Prochlorococcus contributed the most to total phytoplankton biomass $(51 \pm 19 \%)$ followed by Synechococcus $(20 \pm 21 \%)$ (Figure 2c). The Euk-B group comprised $18 \pm 4 \%$ of total phytoplankton biomass owing to their relatively large cell sizes in spite of their low cell number. Although twice more abundant than the Euk-B group, the Euk-A group contributed less $(11 \pm 8 \%)$ to phytoplankton biomass (Figure 2c).

\section{Phytoplankton contribution to $\mathrm{CO}_{2}$ fixation}

Incorporation of ${ }^{14} \mathrm{C}$ tracer into total phototrophic biomass over the time of the incubation, as evidenced by regression analysis $\left(r^{2} \geqslant 98 \%, P<0.05\right)$, followed a simple sigmoidal curve, (Figure 3) indicating that phytoplankton cells were not physiologically impaired during the incubation process, for example, by the slight shifts in light and temperature conditions inherent to the experimental set up. There was no significant dark-driven $\mathrm{CO}_{2}$ fixation, controls incubated in the dark being close to background (Figure 3). Nevertheless, the darkfixation values were subtracted from light mediated $\mathrm{CO}_{2}$ fixation rates. The average light $\mathrm{CO}_{2}$ fixation rate across all 20 stations was $6.5 \pm 3.0 \mathrm{mg} \mathrm{C} \mathrm{m}^{-3} \mathrm{~d}^{-1}$, with a maximum of $12.3 \mathrm{mg} \mathrm{C} \mathrm{m} \mathrm{m}^{-3} \mathrm{~d}^{-1}$ observed close to the Cape Verde Islands (Table 2).

A second set of 100 -times heavier ${ }^{14} \mathrm{C}$-labelled samples was used to determine group-specific contribution to $\mathrm{CO}_{2}$ fixation. The combined $\mathrm{CO}_{2}$ fixation of the total photosynthetic eukaryotes, Prochlorococcus and Synechococcus fitted well the total $\mathrm{CO}_{2}$ fixation measured $(101 \pm 7 \%)$ for the whole unsorted phytoplankton (Table 2). This indicated close to $100 \%$ recovery of flow-sorted cells (Zubkov and Tarran, 2008) as well as an absence of any other major $\mathrm{CO}_{2}$-fixing groups in labelled samples, which remained unsorted. Hence, a $\mathrm{CO}_{2}$ fixation budget for labelled samples could be ascertained. Owing to its high abundance, Prochlorococcus contributed $45 \pm 17 \%$ to $\mathrm{CO}_{2}$ fixation in spite of the low cellspecific rates $\left(1.2 \pm 0.6 \mathrm{fg} \mathrm{C}\right.$ cell $^{-1} \mathrm{~h}^{-1}$, Figures $4 \mathrm{a}$ and b, Table 2). Eukaryotes, on average, contributed approximately a third to total $\mathrm{CO}_{2}$ fixation (34 $\pm 8 \%$ ) measured on the whole unsorted phytoplankton largely because of high cell-specific rates (98 $\pm 50.0 \mathrm{fg} \mathrm{C}$ cell $^{-1} \mathrm{~h}^{-1}$ ). Finally, Synechococcus contributed the least to primary production $(21 \pm 13 \%)$ because of moderate abundance and cell-specific $\mathrm{CO}_{2}$ fixation rates $\left(9.5 \pm 4.3 \mathrm{fg} \mathrm{C}\right.$ cell ${ }^{-1}$ $\mathrm{h}^{-1}$ ). Within the eukaryotes, the Euk-A group was responsible for between $7 \%$ and $19 \%$ of the total $\mathrm{CO}_{2}$ fixed, because of the relatively low $\mathrm{CO}_{2}$ fixation rates of this group $\left(54.3 \pm 19.0 \mathrm{fg} \mathrm{C}\right.$ cell $\left.^{-1} \mathrm{~h}^{-1}\right)$. In contrast, Euk-B had high $\mathrm{CO}_{2}$ fixation rates (196 $\pm 72 \mathrm{fg} \mathrm{C}$ cell ${ }^{-1} \mathrm{~h}^{-1}$, Table 2) and in spite of their low abundance were responsible for $13-38 \%$ of the total $\mathrm{CO}_{2}$ fixed. The biomass-specific $\mathrm{CO}_{2}$ fixation rates (Figure 4c, Table 2) were not significantly different $(t$-test, $P<0.05)$ between the different functional groups analysed here $(0.09 \pm 0.04 \mathrm{mgC}$ $\mathrm{gC}^{-1} \mathrm{~h}^{-1}$ ) although the Prochlorococcus rate was lower $\left(0.06 \pm 0.03 \mathrm{mgC} \mathrm{gC}^{-1} \mathrm{~h}^{-1}\right)$.

\section{Phytoplankton taxonomic composition}

To ascertain the taxonomic composition of the different eukaryotic groups, that is, Euk-A and Euk-B, as well as Prochlorococcus and Synechococcus cyanobacteria, 10 000-pigmented cells from each group were sorted by flow cytometry from concentrated seawater samples at selected stations (see Materials and methods and Table 1) and identified by TSA-FISH (Schönhuber et al., 1997) using classspecific oligonucleotides targeting the nuclear $18 \mathrm{~S}$ rRNA, except for the chrysophytes were a chloroplast-targeted oligonucleotide probe was used (see Materials and methods). The groups observed by flow cytometry in concentrated samples (Supplementary Figure 1) were identical to those in nonconcentrated samples used for the tracer work (see also Zubkov and Tarran, 2008) showing that cell integrity was unaltered by concentrating and processing of samples. For the eukaryotes, the Euk-B group was dominated by prymnesiophytes $(73 \pm 13 \%)$ (Figure 5a), with only minor contributions of pelagophytes $(2 \pm 2 \%)$ and chrysophytes $(8 \pm 8 \%)$ (Table 1). The Euk-A group comprised an assemblage of pelagophytes $(36 \pm 15 \%)$, chrysophytes $(26 \pm 15 \%)$ (Figure $5 \mathrm{~b}$ ) and prymnesiophytes $(16 \pm 11 \%)$.

Prasinophytes and cryptophytes, when detected, accounted for $<4 \%$ of cells in either the Euk-A or 


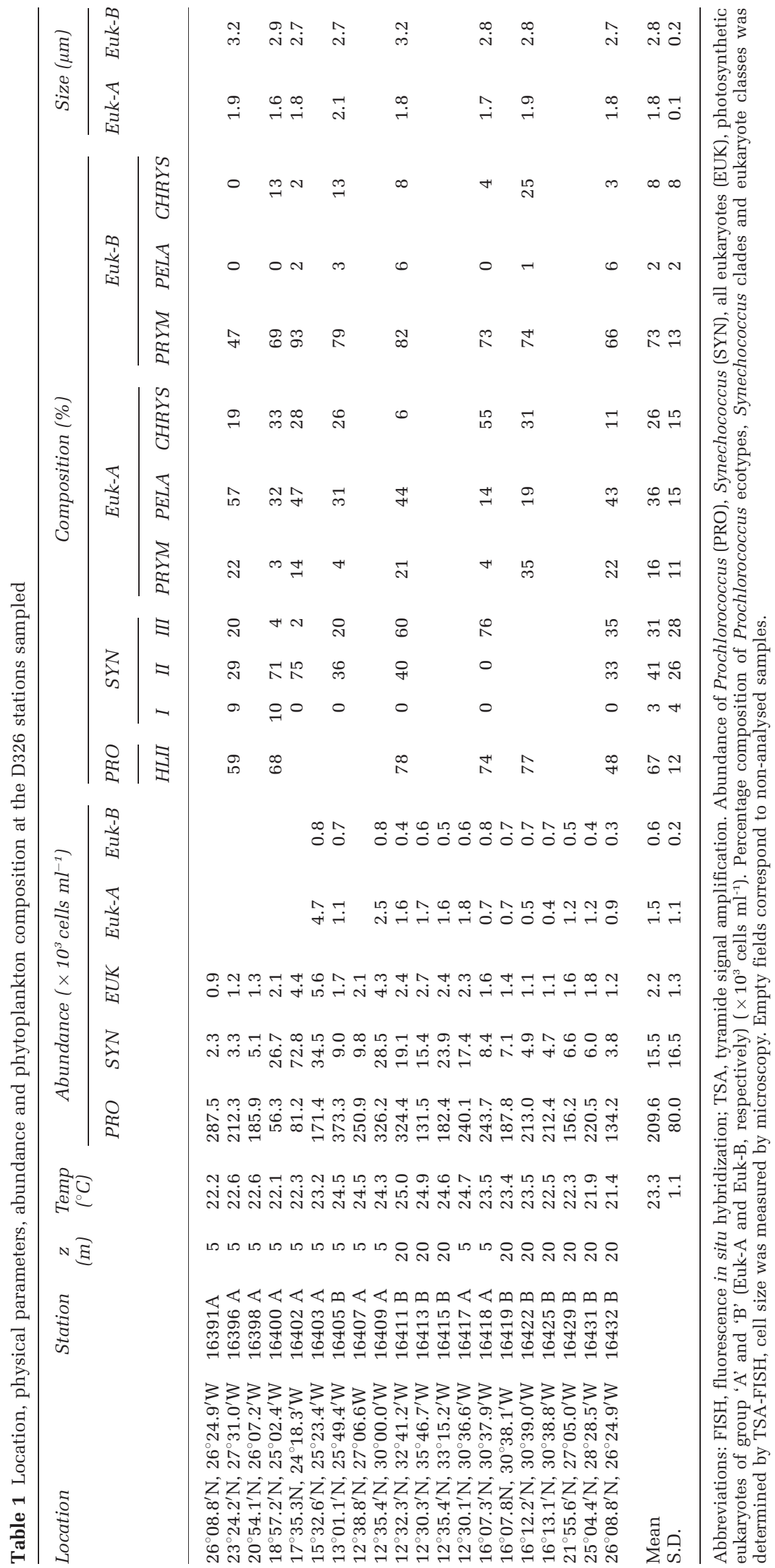


Euk-B group. Phylogenetic analysis of $16 \mathrm{~S}$ rRNA gene sequences obtained from a clone library constructed from flow-sorted Euk-B cells at one location (station 16400A) also showed a dominance of prymnesiophytes. Thus, of the 96 clones analysed, 64\% were affiliated with prymnesiophytes including many sequences unrelated or poorly related (env SOL16400_NE12 and env SOL16400_NF03) to known cultured species

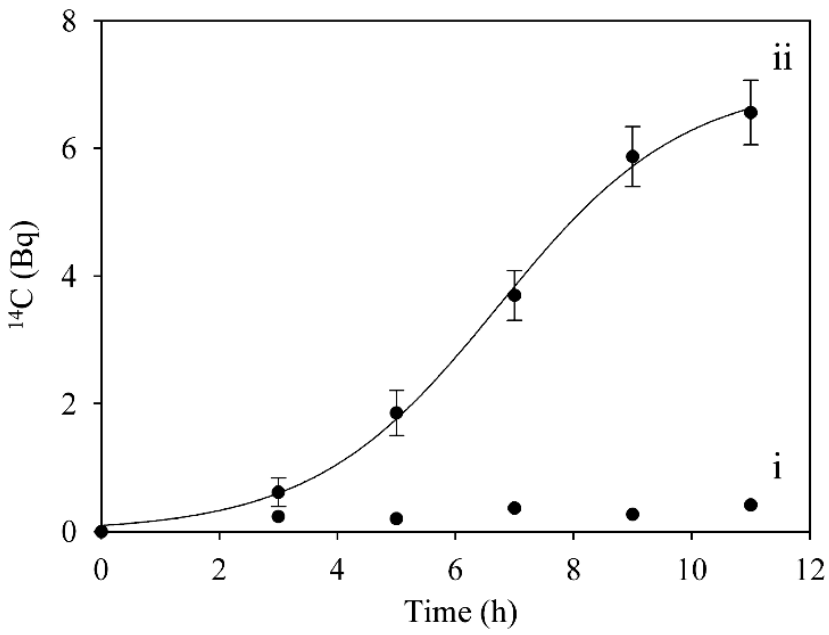

Figure 3 Sigmoid regression approximation $\left(r^{2} \geqslant 98 \%, P<0.05\right)$ of total phytoplankton ${ }^{14} \mathrm{C}$ uptake (Bq) (i) in the dark and (ii) in in situ simulated light conditions during the time course (h) of a typical tracer experiment.
(Figure 6). A more detailed phylogenetic characterization of the Euk-A and Euk-B groups will be presented elsewhere. As evidenced from the FISH data, there was remarkably little variation in taxonomic composition and size of the Euk-A and Euk-B groups (Table 1) indicating this community was largely homogeneous over the course of the study. Averaged over all stations Prochlorococcus comprised mainly $(67 \pm 12 \%)$ cells belonging to the HLII lineage while Synechococcus was composed largely of members of clade II $(41 \pm 26 \%)$ and clade III $(31 \pm 28 \%$ ) (Table 1) (see Fuller et al., 2003 for clade designations).

\section{Discussion}

Assessment of phytoplankton group-specific $\mathrm{CO}_{2}$ fixation by direct radiotracer incorporation has made little progress since the seminal study of Li (1994). In slight contrast to the Li study, however, here we used flow cytometric sorting of fixed cells to determine the precise contribution of different functional groups to $\mathrm{CO}_{2}$ fixation into biomass, because we believe this provides more reproducible estimates compared with sorting of live cells (see Larsen et al., 2008). We should point out though, that while measurement of phytoplankton $\mathrm{CO}_{2}$ fixation using a ${ }^{14} \mathrm{C}$ radiotracer has been used for decades (Steemann-Nielsen, 1952) offering high precision (Irwin, 1991), the method does have some

Table $2 \mathrm{CO}_{2}$ fixation rates at stations along the D326 cruise track in the tropical North Atlantic

\begin{tabular}{|c|c|c|c|c|c|c|c|c|c|c|c|c|c|c|c|}
\hline & \multicolumn{10}{|c|}{$\mathrm{CO}_{2}$ fixation rates $\left({ }^{a} \mathrm{mgC} \mathrm{m}^{-3} d^{-1} ;{ }^{b} f g C \mathrm{Cell}^{-1} h^{-1} ;{ }^{c} \mathrm{mgC} g C^{-1} h^{-1}\right)$} & \multicolumn{5}{|c|}{ Contribution to $\mathrm{CO}_{2}$ fixation (\%) } \\
\hline & Total $^{a}$ & $P R O^{b}$ & $S Y N^{b}$ & $E U K^{b}$ & Euk- $A^{b}$ & $E u k-B^{b}$ & $P R O^{c}$ & $S Y N^{c}$ & Euk- $A^{c}$ & Euk- $B^{c}$ & PRO & $S Y N$ & EUK & Euk-A & Euk-B \\
\hline $16391 \mathrm{~A}$ & 2.5 & 0.6 & 3.4 & 32.0 & & & 0.03 & 0.03 & & & 83 & 4 & 14 & & \\
\hline $16396 \mathrm{~A}$ & 3.3 & 0.7 & 5.8 & 100.3 & & & 0.04 & 0.06 & & & 53 & 7 & 41 & & \\
\hline $16398 \mathrm{~A}$ & 4.2 & 1.4 & 7.7 & 56.7 & & & 0.07 & 0.08 & & & 70 & 11 & 19 & & \\
\hline $16400 \mathrm{~A}$ & 5.1 & 2.4 & 6.1 & 71.6 & & & 0.12 & 0.06 & & & 30 & 37 & 34 & & \\
\hline $16402 \mathrm{~A}$ & 10.5 & 2.3 & 5.9 & 69.3 & & & 0.12 & 0.06 & & & 20 & 47 & 33 & & \\
\hline $16403 \mathrm{~A}$ & 9.7 & 1.3 & 9.6 & 59.9 & 38.5 & 260.3 & 0.07 & 0.10 & 0.06 & 0.11 & 26 & 40 & 40 & 19 & 21 \\
\hline 16405 B & 6.4 & 1.0 & 4.2 & 86.6 & 37.1 & 155.3 & 0.05 & 0.04 & 0.06 & 0.07 & 67 & 7 & 26 & 7 & 19 \\
\hline $16407 \mathrm{~A}$ & 6.1 & 0.9 & 8.0 & 90.7 & & & 0.05 & 0.08 & & & 45 & 15 & 37 & & \\
\hline $16409 \mathrm{~A}$ & 12.3 & 1.2 & 13.5 & 71.2 & 55.1 & 238.9 & 0.06 & 0.14 & 0.09 & 0.10 & 36 & 36 & 29 & 12 & 17 \\
\hline 16411 B & 8.7 & 0.9 & 11.3 & 91.9 & 67.7 & 209.0 & 0.05 & 0.11 & 0.11 & 0.09 & 38 & 29 & 30 & 16 & 13 \\
\hline $16413 \mathrm{~B}$ & 8.6 & 2.1 & 14.8 & 116.2 & 85.5 & 365.5 & 0.11 & 0.15 & 0.14 & 0.16 & 37 & 30 & 41 & 16 & 25 \\
\hline 16415 B & 8.9 & 0.8 & 9.4 & 117.1 & 58.1 & 185.9 & 0.04 & 0.09 & 0.10 & 0.08 & 20 & 29 & 37 & 18 & 19 \\
\hline $16417 \mathrm{~A}$ & 9.6 & 1.3 & 15.7 & 115.8 & & 239.0 & 0.07 & 0.16 & & 0.10 & 39 & 33 & 32 & & 32 \\
\hline $16418 \mathrm{~A}$ & 4.4 & 0.9 & 5.0 & 89.6 & 41.5 & 174.5 & 0.05 & 0.05 & 0.07 & 0.08 & 56 & 11 & 38 & 7 & 31 \\
\hline $16419 \mathrm{~A}$ & 9.4 & 1.9 & 17.1 & 258.4 & 89.4 & 425.5 & 0.10 & 0.17 & 0.15 & 0.19 & 44 & 15 & 44 & 7 & 37 \\
\hline 16422 B & 4.2 & 1.1 & 7.7 & 134.4 & 39.3 & 285.9 & 0.06 & 0.08 & 0.06 & 0.12 & 63 & 10 & 42 & 4 & 38 \\
\hline 16425 B & 5.2 & 1.1 & 8.7 & 150.7 & & 165.0 & 0.06 & 0.09 & & 0.07 & 53 & 9 & 37 & & 37 \\
\hline 16429 B & 6.0 & 0.8 & 15.1 & 139.7 & 48.8 & 248.2 & 0.04 & 0.15 & 0.08 & 0.11 & 25 & 19 & 44 & 14 & 30 \\
\hline 16431 B & 1.8 & 0.3 & 6.3 & 33.6 & 30.1 & 105.6 & 0.02 & 0.06 & 0.05 & 0.05 & 47 & 24 & 39 & 17 & 22 \\
\hline $16432 \mathrm{~B}$ & 3.6 & 1.4 & 14.5 & 73.3 & 60.1 & 162.8 & 0.07 & 0.15 & 0.10 & 0.07 & 58 & 18 & 29 & 14 & 14 \\
\hline Mean & 6.5 & 1.2 & 9.5 & 98.0 & 54.3 & 230.1 & 0.06 & 0.09 & 0.09 & 0.10 & 45 & 21 & 34 & 13 & 25 \\
\hline S.D. & 3.0 & 0.6 & 4.3 & 50.0 & 19.0 & 86.1 & 0.03 & 0.04 & 0.03 & 0.04 & 17 & 13 & 8 & 5 & 9 \\
\hline
\end{tabular}

Rates are presented for the total phytoplankton population ( $\left.\mathrm{mg} \mathrm{C} \mathrm{m}^{-3} \mathrm{~d}^{-1}\right)$, Prochlorococcus (PRO), Synechococcus (SYN), all eukaryotes (EUK) as well as photosynthetic eukaryotes of groups 'A' and 'B' (Euk-A and Euk-B, respectively). The percentage contribution of Prochlorococcus, Synechococcus, Euk-A or Euk-B to the total $\mathrm{CO}_{2}$ fixed is also presented. Empty fields correspond to non-analysed samples. 


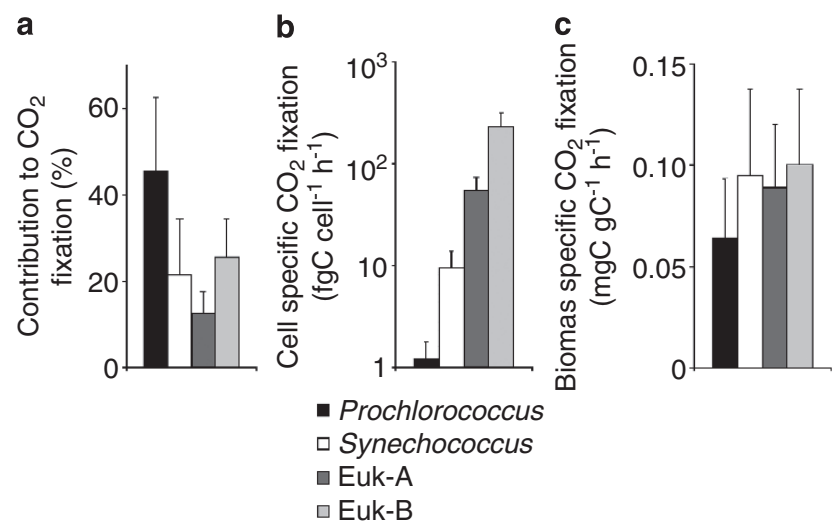

Figure 4 (a) Contribution of the phytoplankton groups Prochlorococcus, Synechococcus, and eukaryotes Euk-A and Euk-B, to total phytoplankton $\mathrm{CO}_{2}$ fixation (b) cell-specific $\mathrm{CO}_{2}$ fixation rates (fgC cell ${ }^{-1} \mathrm{~h}^{-1}$ ) averaged over all stations sampled and (c) biomass-specific $\mathrm{CO}_{2}$ fixation rates $\left(\mathrm{mgC} \mathrm{gC}^{-1} \mathrm{~h}^{-1}\right)$ averaged at stations sampled wherein data were available for all phytoplankton functional groups.

drawbacks including the low specific activity of labelling because of the high natural concentration of (bi)carbonate in seawater. Indeed, ${ }^{14} \mathrm{C}$ added as dissolved inorganic carbon gradually enters pools of particulate and dissolved organic matter. Therefore, in long incubations the dynamics of the labelled carbon cannot accurately represent all transformations between organic and inorganic carbon pools (for example, respiration). Nonetheless, control sortings of heterotrophic bacterioplankton showed no measurable uptake of tracer into biomass (unpublished data) and hence, we feel justified that the ${ }^{14} \mathrm{C}$ radiotracer method can accurately trace inorganic $\mathrm{C}$ assimilation into individual phytoplankton cells. However, as potential light respiration of fixed carbon by phytoplankton cells could occur, the reported specific rates of $\mathrm{CO}_{2}$ fixation into cell biomass should be treated as lower or net estimates.

The total $\mathrm{CO}_{2}$ fixation rates reported here (Figure 4, Table 2) are comparable to previous measurements (for example, see Landry et al., 2000; Pérez et al., 2006; Morán, 2007). Moreover, the large contribution of small phytoplankton (that is, Prochlorococcus, Synechococcus, Euk-A and Euk-B) to $\mathrm{CO}_{2}$ fixation reported here (Figure 4) is also in agreement with previous size-fractionation studies (for example, see Marañón et al., 2001; Pérez et al., 2006). Indeed, Goericke (1998) observed that the contribution to chlorophyll $a$ and primary production of phytoplankton $<3 \mu \mathrm{m}$ in size was almost constant over the year at a station southeast of Bermuda representing as much as $79 \%$ of the total.

Despite Euk-B being the Euk-B being the least abundant phytoplankton group, its contribution to oceanic $\mathrm{CO}_{2}$ fixation reached $38 \%$ of total primary production (Table 2). Given the average cell size of the different functional groups, we might have expected that smaller cells would have competed more efficiently for resources (Raven, 1998) because
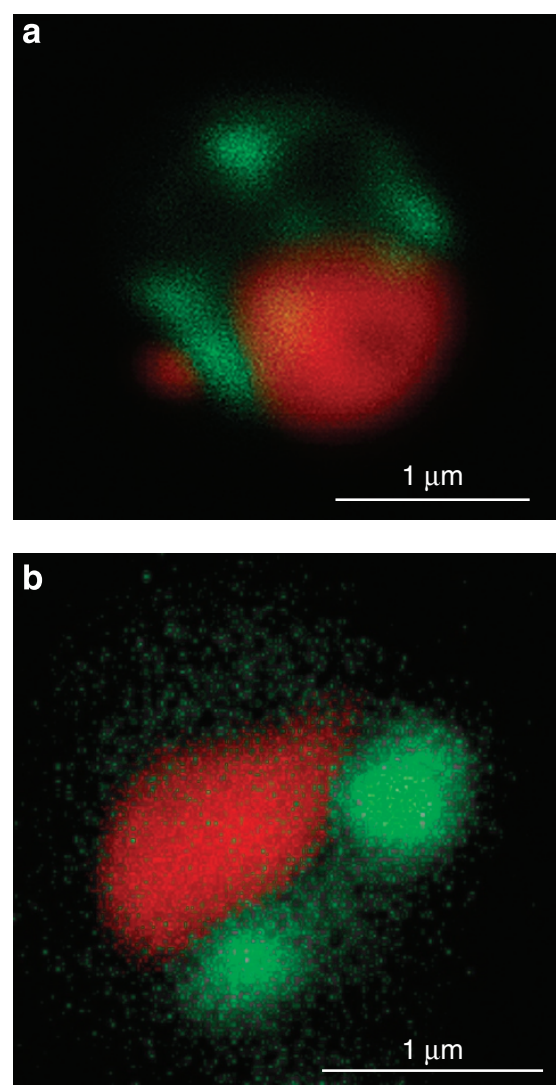

Figure 5 Fluorescence microscope image of a typical cell that was positively labelled with (a) the prymnesiophyte-specific probe or (b) the chrysophyte-specific probe. Green colour shows the positive signal of the horseradish peroxidase (HRP)-labelled probes (a) in the plastids and (b) in the whole cell while the red colour corresponds to the nucleus stained with propidium iodide.

of their high surface area to volume ratios. However, the opposite result confirms that $\mathrm{CO}_{2}$ uptake is more dependent on biovolume than nutrient uptake rates. Interestingly, the lower biomass-specific $\mathrm{CO}_{2}$ fixation rates of Prochlorococcus (Figure 4c) compared with the other functional groups analysed might be explained if Prochlorococcus cells can use harvested light not only for $\mathrm{CO}_{2}$ fixation but also for directly producing adenosine triphosphate to fuel nutrient uptake including the acquisition of organic molecules (Zubkov, 2009). Certainly, it is clear that the Euk-B cells are important carbon fixers because of their high contribution to $\mathrm{CO}_{2}$ fixation in spite of their low cell number. In addition, it is possible that, in spite of their small size, they can participate directly or indirectly to carbon export from the surface ocean (Richardson and Jackson, 2007). This facet may be more pronounced given that small phytoplankton $<5 \mu \mathrm{m}$ in size can also obtain significant carbon intake through bacterivory (Zubkov and Tarran, 2008).

While members of the Prasinophyceae, especially Micromonas spp., are now widely recognized as being the dominant component of the eukaryotic 


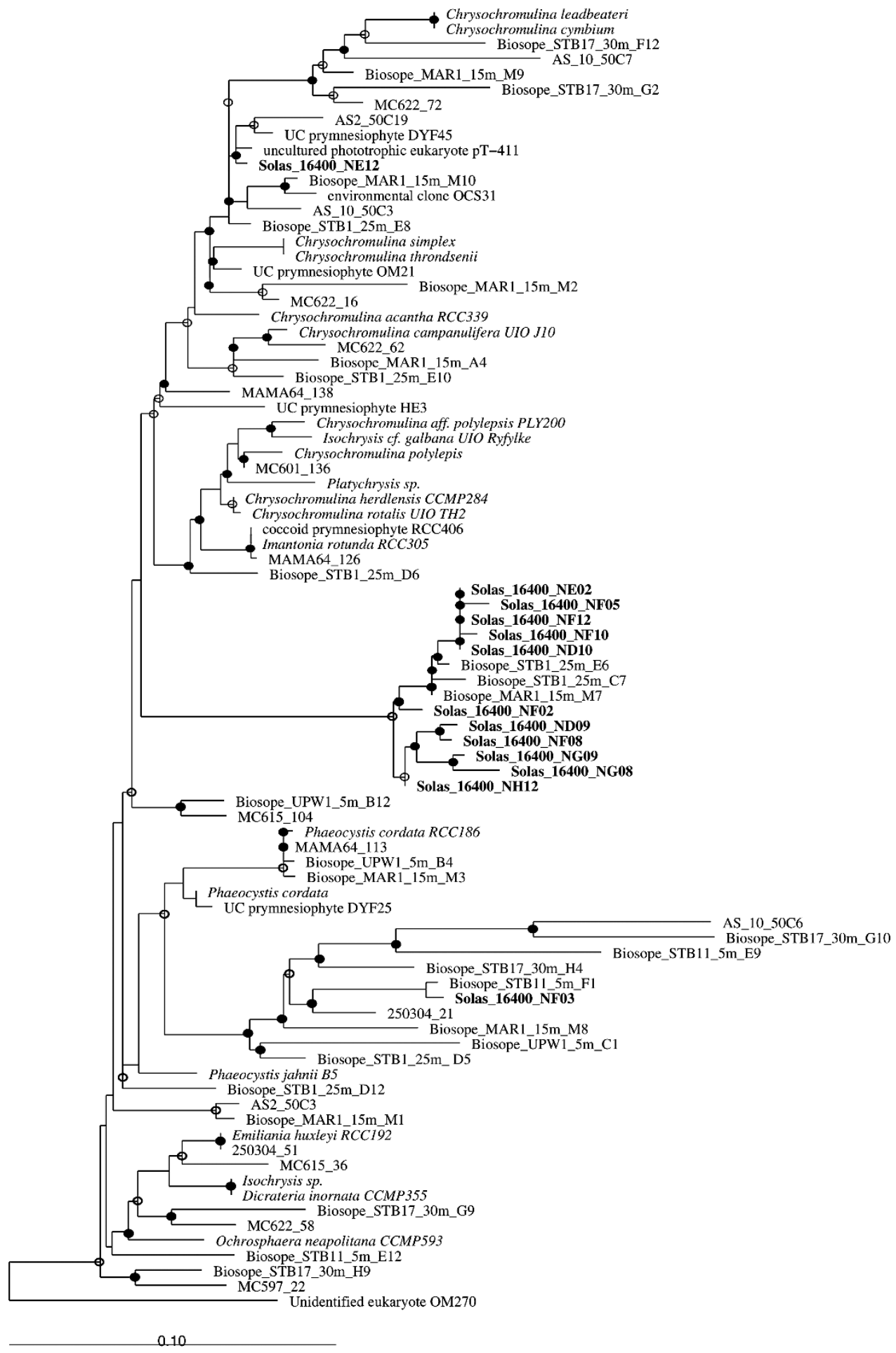

Figure 6 Neighbour joining tree of 16S rRNA gene sequences from marine algal plastids including new sequences derived from flowsorted Euk-B cells at station 16400A. Bootstrap analysis was performed with ARB parsimony bootstrap (Ludwig et al., 2004). @ : values $>90 \%$; $\bigcirc: 70-90 \%$; values < $70 \%$ are not shown. Environmental sequences are as follows: Solas: clones from the D326 cruise; AS: clones from the Arabian Sea (Fuller et al., 2006a); MC and MAMA: clones from the Gulf of Naples (McDonald et al., 2007); DYF: clones from the northwest Mediterranean Sea Dyfamed station (Marie et al., 2006); Biosope: clones from the southeast Pacific Ocean (Lepère et al., 2009).

picophytoplankton in coastal environments (Not et al., 2004; Vaulot et al., 2008), much less is known of the composition of these communities in open ocean waters. The low proportion of prasinophytes observed in this study (Table 1) is consistent then with Micromonas spp. cell numbers decreasing 
rapidly in open ocean waters (Not et al., 2008). However, our use of the PRAS02 probe that targets all Mamiellales except Bathycoccus spp. could lead to the slight underestimation of prasinophytes here, and especially of this latter genus.

While pelagophytes appear to be widely distributed in these environments, though generally found at lower abundance than in this study (Bidigare and Ondrusek, 1996; Díez et al., 2001; Moon-van der Staay et al., 2001; Wilmotte et al., 2002; Romari and Vaulot, 2004; Fuller et al., 2006b; McDonald et al., 2007), there are few reports of members of the class Chrysophyceae in marine systems. While some 'photosynthetic' chrysophytes have been observed by microscopy, these are not abundant and usually refer to cells larger than $5 \mu \mathrm{m}$ (Throndsen, 1996; Novarino et al., 1997). The exception is the order Parmales that encompass a group of small ( $<5 \mu \mathrm{m}$ in diameter), siliceous cells, each with a chloroplast (Booth and Marchant, 1987; Bravo-Sierra and Hernández-Becerril, 2003). However, the chrysophytes observed by microscopy and TSA-FISH here had two chloroplasts, no apparent siliceous deposits in the outer membrane (that is, their $90^{\circ}$ light scatter was similar to other eukaryotic cells) and were smaller than $2.5 \mu \mathrm{m}$ (Figure 5b). Moreover, plastid 16S rRNA gene sequences of photosynthetic chrysophytes have recently been reported from various marine environments (Fuller et al., 2006a, b; McDonald et al., 2007; Lepère et al., 2009) highlighting the potentially wide distribution and ecological importance of this class. Furthermore, 18S rRNA gene sequences of marine chrysophytes forming new groups without cultured representatives and comprising putative photosynthetic organisms have also been retrieved in several recent studies (Worden and Not, 2008; Shi et al., 2009).

Prymnesiophytes were clearly the main component of the Euk-B fraction as determined by FISH analysis. Plastid 16S rRNA gene sequences obtained through clone library construction of sorted Euk-B cells allowed us to ascertain more accurately the composition of the Euk-B group. Subsequent phylogenetic analysis (Figure 6) showed that these prymnesiophytes were closely related to environmental sequences retrieved from the southeast Pacific Ocean encompassing some of the most oligotrophic waters on earth (Lepère et al., 2009) suggesting these lineages have a wide geographic distribution. Moreover, the majority of these sequences were taxonomically affiliated with lineages with no close cultured counterpart. While prymnesiophytes appear widespread in most mesotrophic and oligotophic waters (Bidigare and Ondrusek, 1996; Moon-van der Staay et al., 2000; Díez et al., 2001; Wilmotte et al., 2002; Fuller et al., 2006b; Lepère et al., 2009) and can contribute from $30 \%$ to $50 \%$ of total photosynthetic standing stock across the world ocean (Liu et al., 2009), cultured representatives of the size fractions reported here are still rare. The prymnesiophytes observed in this study are likely not calcified as shown both by microscopy (Figure 5a) and their flow cytometry signature (that is, their $90^{\circ}$ light scatter was similar to other eukaryotic cells) (Supplementary Figure 1) reinforcing the assertion that these prymnesiophytes include novel groups. Indeed, Young et al. (2005) have suggested coccolithophorids represent less than half the existing diversity of Haptophyta. Other studies are beginning to describe the extensive diversity within Haptophyta $<3 \mu \mathrm{m}$ in size (Worden and Not, 2008; Liu et al., 2009). Moreover, recent work (Urein et al., 2007; Zubkov and Tarran, 2008) suggests that oceanic mixotrophy by plastid-containing protists is dominated by small Haptophytalike cells, consistent with both photoautotrophic and mixotrophic trophic modes being observed in cultured prymnesiophytes (for example, Chrysochromunlina sp. and Prymnesium parvum see Kawachi et al., 1991; Jones et al., 1995).

The key role of prymnesiophytes in marine $\mathrm{CO}_{2}$ fixation we show here, is entirely consistent with new estimates of depth-integrated relative abundance of 19'-hexanoyloxyfucoxanthin, an accessory pigment considered characteristic of Haptophyta (though also present in a few other Heterokont algae, see Andersen, 2004), which indicate haptophytes dominate chlorophyll-a-normalized phytoplankton standing stock in the modern ocean (Liu et al., 2009). Further group-specific $\mathrm{CO}_{2}$ fixation data collected at basin scales will be critical to assess the significance of these prymnesiophytes in global primary production. These data will also help to validate models that estimate ocean productivity using chlorophyll $a$-based fluorescence measurements (Behrenfeld et al., 2001). The next crucial step, beyond identification and assessment of their metabolic activities, will be to address the autoecology of the dominant photosynthetic eukaryotes by dissecting the biotic and abiotic factors that control their proliferation in the Ocean (Amann and Fuchs, 2008). Thus, the revealed major role for the prymnesiophyte-dominated phytoplankton group in photosynthetic $\mathrm{CO}_{2}$ fixation in the subtropical and tropical northeast Atlantic Ocean should be considered an important stepping stone towards understanding the Oceans' productivity.

\section{Acknowledgements}

We gratefully acknowledge the captain, officers and crew aboard the RRS Discovery for their help during the cruise. We thank Eric Achterberg and other scientists, involved in the Natural Environment Research Council (NERC) UK Surface Ocean Lower Atmosphere Study (SOLAS) project NE/C001931/1, for an opportunity given to LJ to participate in the cruise. We also thank I Mary for advice on the cell concentrating procedure, W Gaze for sharing microscope facilities, F LeGall and D Vaulot for sharing cultures of the Roscoff Culture Collection and L Lehtovirta and $\mathrm{M}$ Nicoll for optimizing the DNA extraction protocol 
from sorted cells. This study was supported by NERC grant NE/C003160/1 and a NERC funded PhD studentship to JP.

Authors contribution: DJS and MZ designed the study. Tracer work, FISH counts and data analysis was carried out by LJ. Flow cytometry work was performed by MVZ on board and by LJ ashore. JP and LJ constructed the genetic libraries. LJ, MVZ and DJS wrote the paper.

\section{References}

Amann R, Fuchs BM. (2008). Single-cell identification in microbial communities by improved fluorescence in situ hybridization techniques. Nature Rev 6: 339-348.

Andersen RA. (2004). Biology and systematics of heterokont and haptophyte algae. Am J Bot 91: 1508-1522.

Behrenfeld MJ, Randerson JT, McClain CR, Feldman GC, Los SO, Tucker CJ et al. (2001). Biospheric primary production during an ENSO transition. Science 291: 2594-2597.

Bidigare RR, Ondrusek ME. (1996). Spatial and temporal variability of phytoplankton pigment distributions in the central equatorial Pacific Ocean. Deep-Sea Res II 43: 809-833.

Biegala IC, Not F, Vaulot D, Simon N. (2003). Quantitative assessment of picoeukaryotes in the natural environment by using taxon-specific oligonucleotide probes in association with tyramide signal amplificationfluorescence in situ hybridization and flow cytometry. Appl Environ Microbiol 69: 5519-5529.

Booth BC, Marchant HJ. (1987). Parmales, a new order of marine chrysophytes, with descriptions of three new genera and seven new species. J Phycol 23: 245-260.

Bravo-Sierra E, Hernández-Becerril DU. (2003). Parmales (Chrysophyceae) from the Gulf of Tehuantepec, Mexico, including the description of a new species, Tetraparma insecta sp nov, and a proposal to the taxonomy of the group. J Phycol 39: 577-583.

Díez B, Pedrós-Alío C, Massana R. (2001). Study of genetic diversity of eukaryotic picoplankton in different oceanic regions by small-subunit rRNA gene cloning and sequencing. Appl Environ Microbiol 67: 2932-2941.

Foulon E, Not F, Jalabert F, Cariou T, Massana R, Simon N. (2008). Ecological niche partitioning in the picoplanktonic green alga Micromonas pusilla: evidence from environmental surveys using phylogenetic probes. Environ Microbiol 10: 2433-2443.

Fuller NJ, Campbell C, Allen DJ, Pitt FD, Zwirglmaier K, Le Gall F et al. (2006a). Analysis of photosynthetic picoeukaryote diversity at open ocean sites in the Arabian Sea using a PCR biased towards marine algal plastids. Aquat Microb Ecol 43: 79-93.

Fuller NJ, Marie D, Partensky F, Vaulot D, Post AF, Scanlan DJ. (2003). Clade-specific $16 \mathrm{~S}$ ribosomal DNA oligonucleotides reveal the predominance of a single marine Synechococcus clade throughout a stratified water column in the Red Sea. Appl Environ Microbiol 69: $2430-2443$.

Fuller NJ, Tarran GA, Cummings DG, Woodward EMS, Orcutt KM, Yallop M et al. (2006b). Molecular analysis of photosynthetic picoeukaryote community structure along an Arabian Sea transect. Limnol Oceanogr 51: 2502-2514.
Giovannoni SJ, Delong EF, Olsen GJ, Pace NR. (1988). Phylogenetic group-specific oligonucleotide probes for identification of single microbial cells. J Bacteriol 170: $720-726$.

Goericke R. (1998). Response of phytoplankton community structure and taxon-specific growth rates to seasonally varying physical forcing in the Sargasso Sea off Bermuda. Limnol Oceanogr 43: 921-935.

Grob C, Ulloa O, Claustre H, Huot Y, Alarcón G, Marie D. (2007). Contribution of picoplankton to the total particulate organic carbon (POC) concentration in the eastern South Pacific. Biogeosci Discuss 4: 1-37.

Irwin B. (1991). Coulometric measurement of primary production, with comparison against dissolved oxygen and ${ }^{14} \mathrm{C}$ methods in a seasonal study. Mar Ecol Prog Ser 71: 97-102.

Jones HLJ, Durjun P, Leadbeater BSC, Green JC. (1995). The relationship between photoacclimation and phagotrophy with respect to chlorophyll $a$, carbon and nitrogen content, and cell size of Chrysochromulina brevifilum (Prymnesiophyceae). Phycologia 34: 128-134.

Kawachi M, Inouye I, Maeda O, Chihara M. (1991). The haptonema as a food-capturing device: observations on Chrysochromulina hirta (Prymnesiophyceae). Phycologia 30: 563-573.

Landry MR, Constantinou J, Latasa M, Brown SL, Bidigare RR, Ondrusek ME. (2000). Biological response to iron fertilization in the eastern equatorial Pacific (IronEx II). III. Dynamics of phytoplankton growth and microzooplankton grazing. Mar Ecol Prog Ser 201: 57-72.

Larsen A, Tanaka T, Zubkov MV, Thingstad TF. (2008). P-affinity measurements of specific osmotroph populations using cell-sorting flow cytomtery. Limnol Oceanogr Meth 6: 355-363.

Latasa M, Bidigare RR. (1998). A comparison of phytoplankton populations of the Arabian Sea during the spring intermonsoon and southwest monsoon of 1995 as described by HPLC-analyzed pigments. Deep Sea Res Pt II 45: 2133-2170.

Lepère C, Vaulot D, Scanlan DJ. (2009). Photosynthetic picoeukaryote community structure in the south east Pacific Ocean encompassing the most oligotrophic waters on Earth. Environ Microbiol 11: 3105-3117.

Li WKW. (1994). Primary productivity of prochlorophytes, cyanobacteria, and eucaryotic ultraphytoplankton: measurements from flow cytometric sorting. Limnol Oceanogr 39: 169-175.

Liu H, Aris-Brosou S, Probert I, de Vargas C. (2010). A timeline of the environmental genetics of the haptophytes. Mol Biol Evol 27: 161-176.

Liu H, Probert I, Uitz J, Claustre H, Aris-Brosou S, Frada M et al. (2009). Extreme diversity in noncalcifying haptophytes explains a major pigment paradox in open oceans. Proc Natl Acad Sci USA 106: 12803-12808.

Ludwig W, Strunk O, Westram R, Richter L, Meier H, Yadhukumar et al. (2004). ARB: a software environment for sequence data. Nucl Acids Res 32: 1363-1371.

Marañón E, Holligan PM, Barciela R, Gonzalez N, Mourino B, Pazo MJ et al. (2001). Patterns of phytoplankton size structure and productivity in contrasting open-ocean environments. Mar Ecol Prog Ser 216: 43-56.

Marañón E, Holligan PM, Varela M, Mouriño B, Bale AJ. (2000). Basin-scale variability of phytoplankton biomass, production and growth in the Atlantic Ocean. Deep-Sea Res I 47: 825-857. 
Marie D, Zhu F, Balagúe V, Ras J, Vaulot D. (2006). Eukaryotic picoplankton communities of the Mediterranean Sea in summer assessed by molecular approaches (DGGE, TTGE, QPCR). FEMS Microbiol Ecol 55: 403-415.

McDonald SM, Sarno D, Scanlan DJ, Zingone A. (2007). Genetic diversity of eukaryotic ultraphytoplankton in the Gulf of Naples during an annual cycle. Aquat Microb Ecol 50: 75-89.

Moon-van der Staay SY, De Wachter R, Vaulot D. (2001). Oceanic $18 \mathrm{~S}$ rDNA sequences from picoplankton reveal unsuspected eukaryotic diversity. Nature 409: $607-610$.

Moon-van der Staay SY, van der Staay GWM, Guillou L, Vaulot D. (2000). Abundance and diversity of prymnesiophytes in the picoplankton community from the equatorial Pacific Ocean inferred from 18S rDNA sequences. Limnol Oceanogr 45: 98-109.

Morán XAG. (2007). Annual cycle of picophytoplankton photosynthesis and growth rates in a temperate coastal ecosystem: a major contribution to carbon fluxes. Aquat Microb Ecol 49: 267-279.

Neufeld JD, Vohra J, Dumont MG, Lueders T, Manefield M, Friedrich MW et al. (2007). DNA stable-isotope probing. Nat Methods 2: 860-866.

Not F, Latasa M, Marie D, Cariou T, Vaulot D, Simon N. (2004). A single species Micromonas pusilla (Prasinophyceae) dominates the eukaryotic picoplankton in the western English Channel. Appl Environ Microbiol 70: 4064-4072.

Not F, Latasa M, Scharek R, Viprey M, Karleskind P, Balague $\mathrm{V}$ et al. (2008). Protistan assemblages across the Indian Ocean, with a specific emphasis on the picoeukaryotes. Deep-Sea Res I 55: 1456-1473.

Not F, Simon N, Biegala IC, Vaulot D. (2002). Application of fluorescent in situ hybridization coupled with tyramide signal amplification (FISH-TSA) to assess eukaryotic picoplankton composition. Aquat Microb Ecol 28: 157-166.

Novarino G, Mills DK, Hannah F. (1997). Pelagic flagellate populations in the southern North Sea, 1988-89. I. Qualitative observations. J Plankton Res 19: 1081-1109.

Pérez V, Fernández E, Marañón E, Morán XAG, Zubkov MV. (2006). Vertical distribution of phytoplankton biomass, production and growth in the Atlantic subtropical gyres. Deep-Sea Res I 53: 1616-1634.

Poulton AJ, Holligan PM, Hickman A, Kim YN, Adey TR, Stinchcombe MC et al. (2006). Phytoplankton carbon fixation, chlorophyll-biomass and diagnostic pigments in the Atlantic Ocean. Deep-Sea Res II 53: 1593-1610.

Raven JA. (1998). The twelfth tansley lecture. Small is beautiful: the picophytoplankton. Functional Ecol 12: 503-513.

Richardson TL, Jackson GA. (2007). Small phytoplankton and carbon export from the surface ocean. Science 315: 838-840.

Romari K, Vaulot D. (2004). Composition and temporal variability of picoeukaryote communities at a coastal site of the English Channel from 18S rDNA sequences. Limnol Oceanogr 49: 784-798.

Schönhuber W, Fuchs B, Juretschko S, Amann R. (1997). Improved sensitivity of whole-cell hybridization by the combination of horseradish peroxidase-labeled oligonucleotides and tyramide signal amplification. Appl Environ Microbiol 63: 3268-3273.

Shi XL, Marie D, Jardillier L, Scanlan DJ, Vaulot D. (2009). Groups without cultured representatives dominate eukaryotic picophytoplankton in the oligotrophic south east Pacific Ocean. PLoS One 4: e7657.

Simon N, Campbell L, Ornolfsdottir E, Groben R, Guillou L, Lange $\mathrm{M}$ et al. (2000). Oligonucleotide probes for the identification of three algal groups by dot blot and fluorescent whole-cell hybridization. J Euk Microbiol 47: 76-84.

Simon N, Lebot N, Marie D, Partensky F, Vaulot D. (1995). Fluorescent in situ hybridization with rRNA-targeted oligonucleotide probes to identify small phytoplankton by flow cytometry. Appl Environ Microbiol 61: 2506-2513.

Steemann-Nielsen E. (1952). The use of radioactive carbon $\left({ }^{14} \mathrm{C}\right)$ for measuring organic production in the sea. $J$ Cons Int Explor Mer 18: 117-140.

Teira E, Mourino B, Marañón E, Perez V, Pazo MJ, Serret P et al. (2005). Variability of chlorophyll and primary production in the Eastern North Atlantic Subtropical Gyre: potential factors affecting phytoplankton activity. Deep-Sea Res I 52: 569-588.

Throndsen J. (1996). The planktonic marine flagellates. In: Tomas CR (ed). Identifying Marine Phytoplankton. Academic Press: San Diego, pp 591-730.

Urein F, Massana R, Alonso-Sáez L, Gasol JM. (2007). Significant year-round effect of small mixotrophic flagellates on bacterioplankton in an oligotrophic coastal system. Limnol Oceanogr 52: 456-469.

Vaulot D, Eikrem W, Viprey M, Moreau H. (2008). The diversity of small eukaryotic phytoplankton $(<3 \mu \mathrm{m})$ in marine ecosystems. FEMS Microbiol Rev 32: 795-820.

Viprey M, Guillou L, Ferréol M, Vaulot D. (2008). Wide genetic diversity of picoplanktonic green algae (Chloroplastidia) in the Mediterranean Sea uncovered by a phylum-biased PCR approach. Environ Microbiol 10: 1804-1822.

West NJ, Schönhuber WA, Fuller NJ, Amann RI, Rippka R, Post AF et al. (2001). Closely related Prochlorococcus genotypes show remarkably different depth distributions in two oceanic regions as revealed by in situ hybridisation using 16S rRNA-targeted oligonucleotides. Microbiology 147: 1731-1744.

Wilmotte A, Demonceau C, Goffart A, Hecq JH, Demoulin V, Crossley AC. (2002). Molecular and pigment studies of the picophytoplankton in a region of the Southern Ocean (42-541S, 141-1441E) in March 1998. DeepSea Res II 49: 3351-3363.

Worden AZ, Nolan JK, Palenik B. (2004). Assessing the dynamics and ecology of marine picophytoplankton: the importance of the eukaryotic component. Limnol Oceanogr 49: 168-179.

Worden AZ, Not F. (2008). Ecology and diversity of picoeukaryotes. In: Kirchman DL (ed). Microbial Ecology of the Ocean. John Wiley \& Sons, Inc.: New York, pp 159-196.

Wright SW, Ishikawa A, Marchant HJ, Davidson AT, van den Enden RL, Nash GV. (2009). Composition and significance of picophytoplankton in Antarctic waters. Polar Biol 32: 797-808.

Young JR, Geisen M, Probert I. (2005). A review of selected aspects of coccolithophore biology with implications for paleobiodiversity estimation. Micropaleontology 51: 267-288.

Zubkov MV. (2009). Photoheterotrophy in marine prokaryotes. J Plankton Res 31: 933-938.

Zubkov MV, Sleigh MA, Burkill PH, Leakey RJG. (2000). Picoplankton community structure on the Atlantic Meridional Transect: a comparison between seasons. Prog Oceanogr 45: 369-386. 
Zubkov MV, Burkill PH. (2006). Syringe pumped high speed flow cytometry of oceanic phytoplankton. Cytometry Part A 69A: 1010-1019.

Zubkov MV, Burkill PH, Topping JN. (2007). Flow cytometric enumeration of DNA stained oceanic planktonic protists. J Plankton Res 29: 79-86.
Zubkov MV, Leakey RJ. (2009). Evaluation of the efficiency of metabolism of dinoflagellate phosphorus and carbon by a planktonic ciliate. Eur J Protist 45: 166-173.

Zubkov MV, Tarran GA. (2008). High bacterivory by the smallest phytoplankton in the North Atlantic Ocean. Nature 455: 224-227.

Supplementary Information accompanies the paper on The ISME Journal website (http://www.nature.com/ismej) 